\title{
Impact of Various
} \section{Range}

\section{Abstract}

During 1976 a study of annual production and cover (litter + rock + vegetation) on various range improvement practices was conducted in Utah, Colorado, New Mexico, and Arizona. The range improvement practices studied included gully plugs, contour furrowing, pitting, pinyon-juniper chaining, and various sagebrush control treatments.

Results from studies of annual production on treated vs untreated sites indicated that: (a) about $33 \%$ of the contour furrowed sites had significant increases in annual production. Best responses were found on loam and clay loam soils, while soils of sandy loam or clay texture indicated a poor response to treatment. Soils classified as typical ustifluvents and ustollic haplargids were most favorable in terms of increased production; (b) annual production on pinyon-juniper chainings was significantly increased across a variety of soil types (growth of trees excluded). The greatest increases in production were measured on sites with loam soils classified as typic haplustolls; (c) neither of the two pitting treatments on a clay and a sandy clay loam site indicated increased annual production; (d) less than $50 \%$ of the various sagebrush treatments indicated increased annual production. There appears to be a general trend for best responses on loam soils, though significant decreases in production were also indicated on this type of soil; (e) plowing was the least successful sagebrush treatment studied.

Best cover responses on the various range improvement practices were found on contour furrowing treatments on sandy clay loam and loam textured soils and on typic torriorthent or ustic torriorthent soil types. Though significant cover increases due to chaining of pinyon and juniper were noted on $57 \%$ of the treatments, on a variety of soil textures and soil types, the

The authors are graduate research assistant and associate professor. Rangeland Hydrology, Watershed Science Unit, College of Natural Resources, Utah State University. Logan 84322

The research was supported jointly by the Bureau of Land Management (Contract 5250(0-(TS-16) and the Utah Agricultural Experiment Station. Project 412. The authors would like to thank Dr. Al Southard. Department of Soils and Biometeorology. Utah State University, for his assistance in classification of soils. Journal Paper 2280, Utah Agricultural Experiment Station.

Manuscript received March 28, 1978. increases were uniformly small (tree cover included) and no clear pattern emerged with either soil texture or soil type. Only about $20 \%$ of the various sagebrush treatments showed significant increases in cover; $10 \%$ indicated decreased cover, and there was no impact on cover on the remaining $70 \%$ of the treatments. Pitting treatments in this study had no impact on cover.

Age of contour furrow treatments made little difference as to whether there was a significant increase or decrease in either production or cover. Cover data from pinyon-juniper chainings indicate either that significant increases in cover (if they occur) are slightly more dramatic on more recent treatments, or that treatments approximately 11 years old represent conditions most ideal for enhanced cover. The former interpretation is probably more nearly correct. Production data suggests that pinyon-juniper sites chained since 1964 are not as favorable in terms of increased production as those chained prior to 1964. Age of sagebrush treatment had no inpact on significant changes in cover; however, a general trend indicated that production increases are slightly higher for more recent sagebrush ripping and sagebrush chaining treatments than for older ones.

The upper and lower Colorado River basins, rapidly growing in population and size, face increasing problems concerning water quality. The concern is particularly noticeable in terms of the increasing dissolved solid content of the Colorado River itself. The growing awareness that chemical constituents are an integral part of the hydrologic system has led to a greater emphasis on determining sources and causes of dissolved solids and their relationship to physical system parameters. One particular aspect of current interest is the determination of the impacts of various rangeland manipulation treatments on salinity. If such impacts can be identified, then strategies may be developed for decreasing the salinity problem and improving water quality. The major emphasis of this study is directed to the practical application of range improvement practices for eventual formulation of land management programs that may 
influence infiltration and surface run-off and help reduce the diffuse salt production from wildland watersheds.

The objective of this study was to determine the impact of existing land treatments on watershed cover and annual production. Reviews of the impact of various range improvements practices on selected watershed characteristics have recently been given by Gifford (1975) and Wight (1975).

\section{General Description of Study Area}

The 73 study sites are located primarily in Utah, Colorado, and New Mexico, with one site in Arizona. The range improvement practices studied included contour furrowing (11 sites), pitting (2 sites), pinyon-juniper chaining (14 sites), gully plugs (6 sites), and various sagebrush control treatments ( 40 sites). The sites in Utah (32 sites) lie primarily in Grand, Emery, Carbon, and San Juan counties; in Colorado (12 sites) Montrose, Gunnison, Dolores, and San Miguel counties; in New Mexico (28 sites), Valencia, Sandoval, Rio Arriba, and San Juan counties; and Maricopa county in Arizona (1 site).

The highest point among the sites is $2,438 \mathrm{~m}$ above sea level in San Juan county in Utah, and the lowest is $396 \mathrm{~m}$ in Maricopa county in Arizona. The Canyonlands country, located in the Colorado plateau province, is characterized by many deep, rugged canyons through which flows the Colorado River. The major part of the area is composed of tablelands, or mesas, and the topography is undulating to gently rolling. In Colorado and New Mexico the terrain is gentle, and the sites are located mainly on recent alluvium and alluvial fans. Generally, pinyon-juniper chaining practices are located at higher elevations in rougher terrains than are most of the other improvement practices. The mean annual temperature among the various sites ranges from $9.4^{\circ} \mathrm{C}$ to $11.6^{\circ} \mathrm{C}$. Most of the sites, except those at higher elevations, have a mesic soil temperature regime. The higher elevation sites are considered frigid.

Precipitation varies markedly among the sites, with the average annual precipitation varying from $18 \mathrm{~cm}$ to almost $75 \mathrm{~cm}$. The climate is characterized by cold winters and relatively hot and dry summers, with the highest rainfall in August, September and October, and the lowest during May and June. Much of the precipitation in summer falls as showers and the resulting moisture is rapidly evaporated or transpired.

Parent material on the study sites varies. Most of the soils on the gully plug sites, and also on a few contour furrow sites, were formed on parent materials derived from soft shale and sandstone of Cretaceous and early Tertiary ages called the Mancos formation (Wilson 1975). Other sources of parent materials include a brown mantle of eolian sediments, calcareous sandstones, glacial tills, hardshales, and recent or old alluvial deposits. Soils at high elevations (Mollisols, Alfisols) are commonly leached, well developed, and acid in reaction. This is due to higher precipitation, lower temperature, and coniferous type trees. On sites where annual rainfall is lower, leaching of carbonates from the soil is not well developed (Aridisols), and there has been little translocation of clay in the profile (Wilson 1975).

Vegetation on the various sites varies with elevation, amount of precipitation, seasonal distribution of moisture, and soil characteristics. In general, native plant communities in the lower valleys, plains, mesas, and plateaus, where the climate is semiarid and average annual precipitation is low, are dominated by grasses, shrubs, and forbs. Species such as mat saltbrush (Atriplex corrugata), nuttal saltbush (Atriplex nuttallii), fourwing saltbush (Atriplex canescens), shadscale (Atriplex confertifolia), greasewood (Sarcobatus vermiculatus), Indian ricegrass (Oryzopsis hymenoides), and galleta (Hilaria jamesii) are most dominant in saline soil sites. However, on sites with less salt, true mountain mahogany (Cercocarpus montanus), bitterbrush (Purshia tridentata), gamble oak (Quercus gambelii), serviceberry (Amelanchier alnifolius), rabbitbrush (Chrysothamnus viscidiflorus), snake weed (Xanthocephalum sarothrae), big sagebrush (Artemisia tridentata), alkali sacaton (Sporobolus airoides), sand dropseed (Sporobolus cryptandrus), and blue grama (Bouteloua gracilis) are found. At higher elevations pinyon-pine (Pinus edulis) and Utah juniper (Juniperus osteosperma) are the dominant species that are found mainly on mountain slopes, plateaus, and foothill terraces on shallow and stony areas where the climate is dry-subhumid

During the period from 1945 to 1970 , vegetation conversion practices were attempted on the various study sites. The primary purpose of the conversion practices was to improve range condition through increasing soil moisture, grazing capacity, and nutritional value of forage. Crested wheatgrass (Agropyron cristatum), tall wheatgrass (Agropyron elongatum), western wheatgrass (Agropyron smithii), Russian wildrye (Elymus juncus), side-oats grama (Bouteloua curtipendula), alkali sacaton (Sporobolus airoides), sand dropseed (Sporobolus cryptandrus), sweet clover (Mellilotous officinalis), and fourwing saltbush (Atriplex canescens), are the main species which were seeded on the various sites.

\section{Methods and Procedure}

This study was initiated early in 1976. Job documentation reports and information from the appropriate Bureau of Land Management districts on the age of various range improvement treatments, acreage involved, geographic location, and methods of applying treatments were used for determining the approximate number of sites to be sampled. Topographical maps were used to determine the general location of various sites, while field visits established the exact location of sampling sites. Specific criteria such as the representativeness of the gencral area were considered in final site selections.

A "treated" and nearby similar "untreated" sampling site, each with an area of approximately $23,409 \mathrm{~m}^{2}(2.3 \mathrm{ha})$, were selected for each treatment location. All on-site measurements and observations were taken only once at each site. Statistical evaluations were made of treated vs untreated conditions within a given location for a single sampling date.

Soil at all sites was classified in the field according to procedures outlined in U.S. Dep. Agr. Handbook No. 436 (1975).

Current year's production of all species present (green weight estimates were later converted to air-dry weight) in "treated" and nearby "untreated" sites was measured using a double-sampling technique modified after the weight estimate method (Pechanec and Pickford 1937). Production was not determined on gully plug treatments. Samples were taken along transect lines using a circular $0.89-\mathrm{m}^{2}\left(9.6-\mathrm{ft}^{2}\right)$ hoop at intervals of $18 \mathrm{~m}$ between plots. Twentyfive random plots were selected and measured on each area and every fifth plot (beginning with the first) was also clipped. Regression techniques were used to adjust all estimated plots. Production measurements were taken only on ungrazed or lightly grazed portions of each treatment site.

Canopy and ground cover (including litter and rock) of all species were measured on all sampling sites using the step-point method of sampling (Evans and Love 1957). Fifty points were read on each of four transects, for a total of 200 points per treatment. As with production measures, cover measurements were taken only on ungrazed or lightly grazed portions of each treatment site.

\section{Production Measures \\ Contour Furrowing}

Figures 1 and 2 indicate significant changes in annual production on various contour furrowing projects as a function of soil texture and soil type, respectively. From Figure 1 it is evident that a poor response to contour furrowing is generally associated with sandy loam and clay soils. In this study, no significant increases in production were noted on sites with soils in these textural classes. Increased production due to furrowing was measured on one. site (out of two) on loam soils and on one site (out of three) on clay loam soils. There were no significant decreases in production as a result of contour furrowing on either the loam or clay loam soils

From Figure 2 it is apparent that production on contour furrowing treatments is significantly increased on typic usti- 


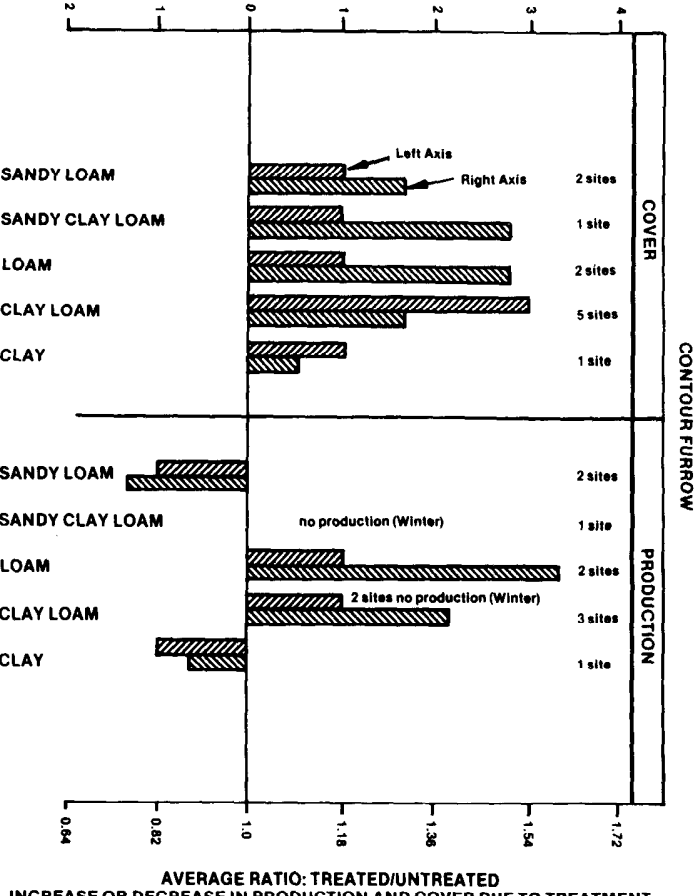

INCREASE OR DECREASE IN PRODUCTION AND COVER DUE TO TREATMENT

Fig. 1. Response of cover (vegetation, litter, rock) and production (all species) on various contour furrowing projects as a function of soil texture. For each pair of bars, the left bar corresponds to the left axis and the right bar corresponds to the right axis. Site numbers above or below each set of bars represent total number of sites sampled within a given category.

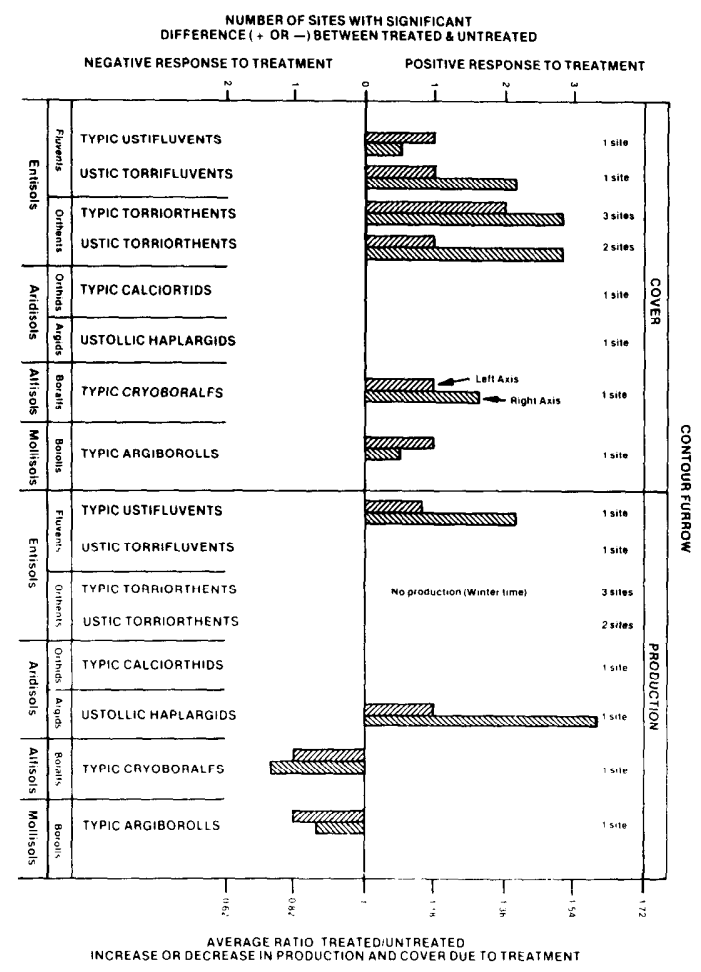

Fig. 2. Response of cover (vegetation, litter, rock) and production (all species) on various contour furrowing treatments as a function of soils. For each pair of bars, the left bar corresponds to the left axis and the right bar corresponds to the right axis. Site numbers above or below each set of bars represent total number of sites sampled within a given category. Bars represented only those sites where significant differences $(\mathrm{P}=0.1)$ occurred (either + or -$)$.
NEGATIVE AESPONSE TO TREATMENT POSITIVE RESPONSE TO TREATMENT

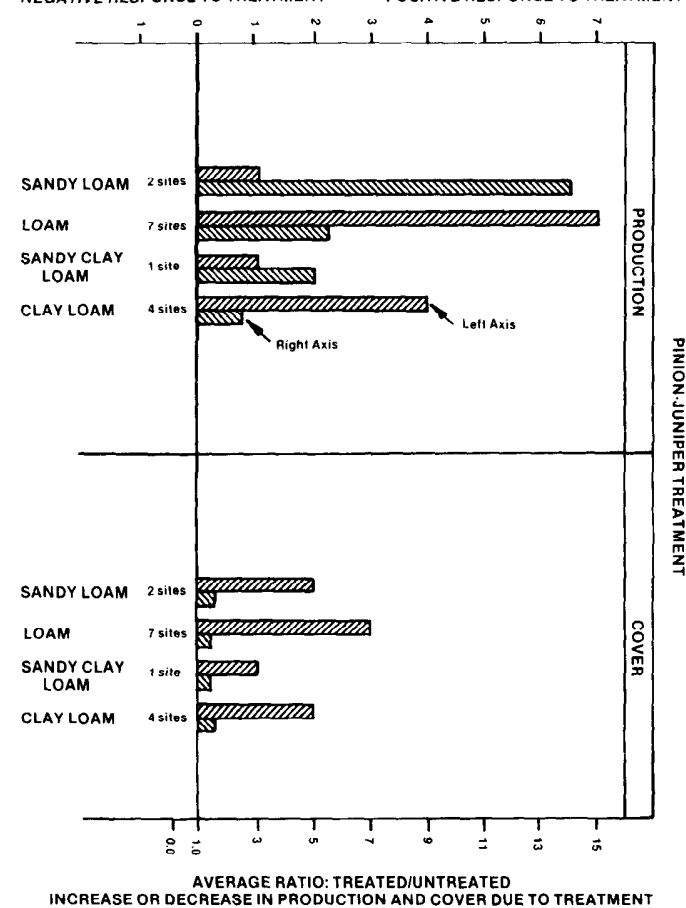

Fig. 3. Response of cover (vegetation, litter, rock) and production (all species excluding pinyon and juniper trees) on various pinyon-juniper treatments chaining and seeding) as a function of soil texture. For each pair of bars, the left bar corresponds to the left axis and the right bar corresponds to the right axis. Site numbers above or below each set of bars represent total number of sites sampled within a given category. Bars represent only those sites where significant differences $(\mathrm{P}=0.1)$ occurred (either + or - ).

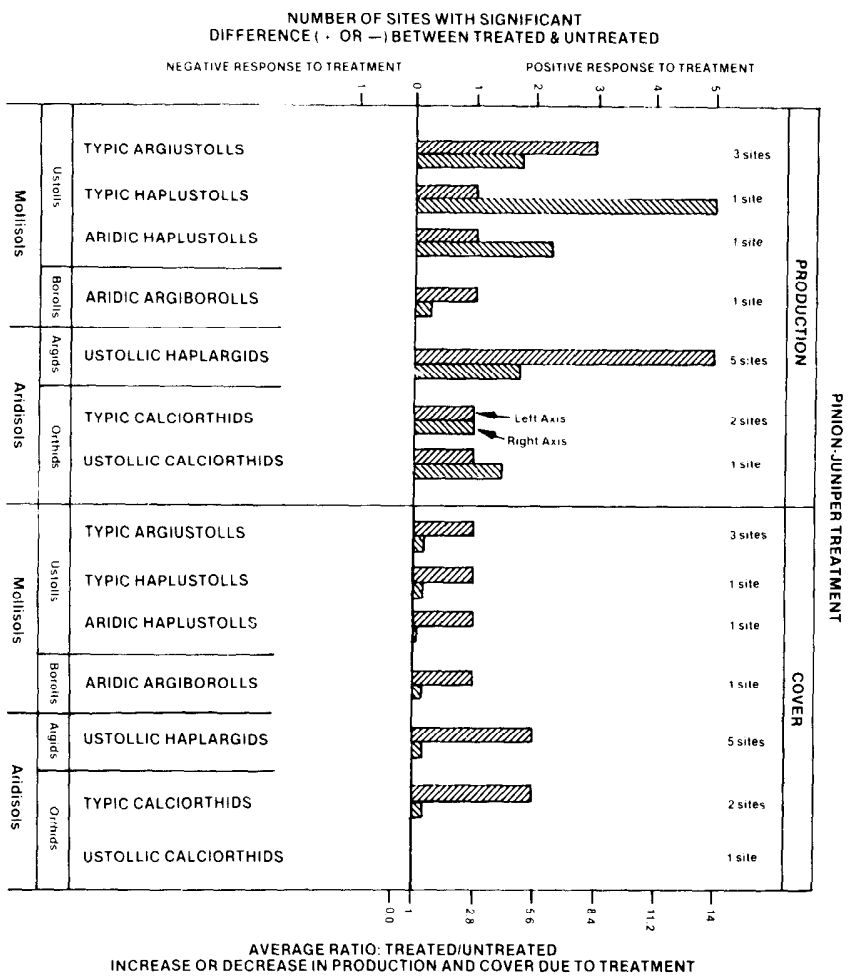

Fig. 4. Response of cover (vegetation, litter, rock) and production (all species) on various pinyon-juniper treatments (chaining and seeding) as a function of soils. For each pair of bars, the left bar corresponds to the left axis and the right bar corresponds to the right axis. Site numbers above or below each set of bars represent total number of sites sampled within a given category. Bars represent only those sites where significant differences $(\mathrm{P}=0.1)$ occurred either + or - ). 
fluvents and ustollic haplargid soils. Annual production on contour furrowed sites with typic cryboralf and typic argiboroll soils was significantly decreased (one site each). No significant changes in annual production were measured on sites with other soil types.

\section{Pinyon-Juniper Chaining}

Figure 3 shows the impact of pinyon-juniper chaining on annual production as a function of soil texture. There was a significant increase in production on nearly all chained sites. The greatest increase in production was measured on sites with coarser loam soils, with lesser increase on sites with clay loam soils.

Figure 4 indicates that annual production was significantly increased across a variety of soil types. The greatest increase was on one site characterized by a typic haplustoll.

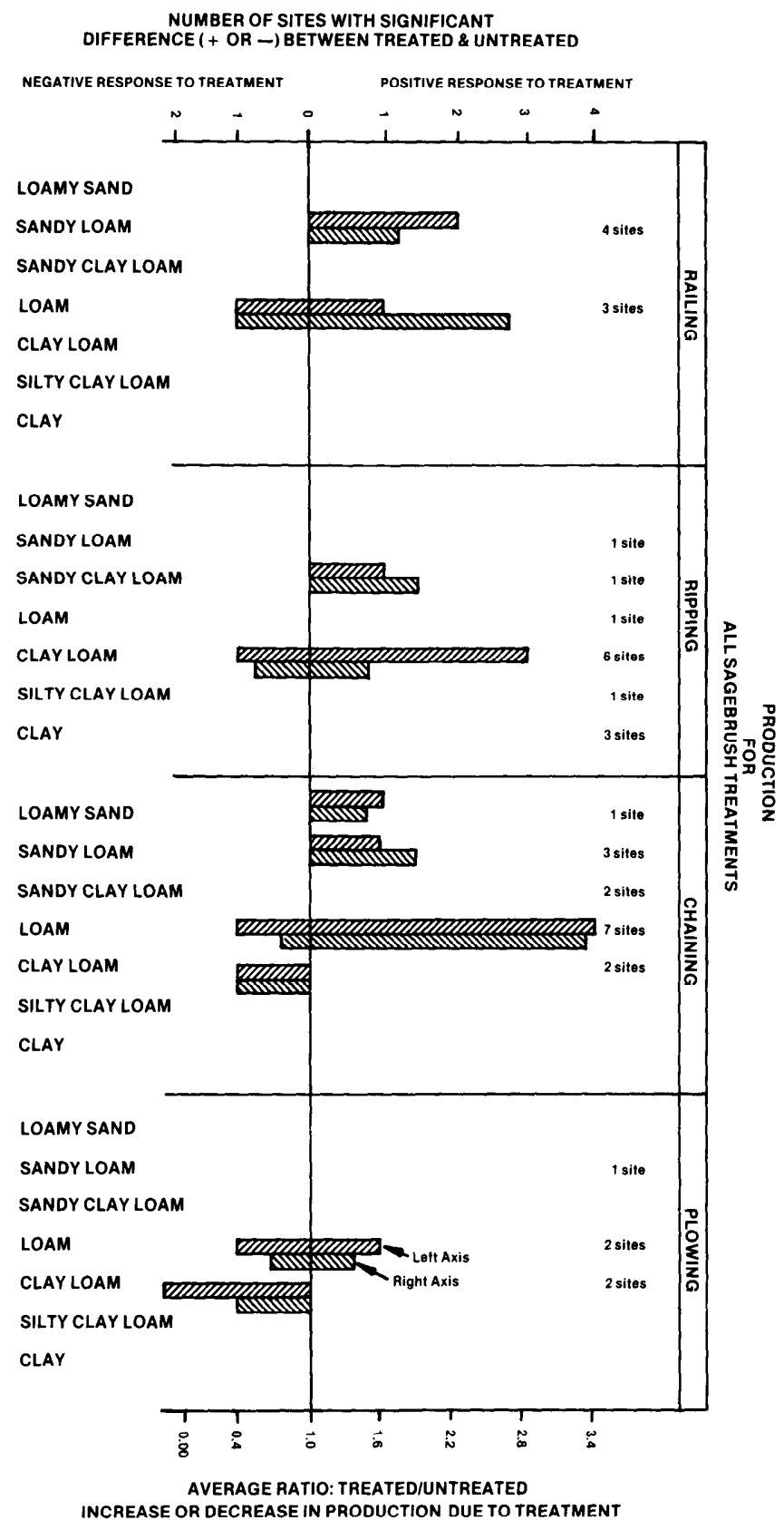

Fig. 5. Response of production (all species) on various sagebrush treatments as a function of soil texture. For each pair of bars the left bar corresponds to the left axis and the right bar corresponds to the right axis. Site numbers above or below each set of bars represent total number of sites sampled within a given category. Bars represent only those sites where significant differences $(\mathrm{P}=0.1)$ occurred either + or -$)$.

\section{Pitting}

On the two pitting treatments a significant reduction in annual production due to treatment was noted on clay soils, while on a sandy clay loam site no impact of pitting was measured. Soil on the former site was classified as a typic torriorthent and on the latter site as a typic torrifluvent.

\section{Various Sagebrush Treatments}

Figures 5 and 6 show the variable production response among various sagebrush treatments as a function of soil texture and soil type, respectively. There appears to be a general trend for sagebrush treatments to be most successful on loam soil, though significant decreases in production were noted for three treatments on loam soils. Plowing was the least successful sagebrush treatment studied.

\section{Sagebrush Railing}

Figure 5 indicates that annual production was significantly increased on two out of four sites on sandy loam soils and on one of three sites on loam soils. Annual production on one site with

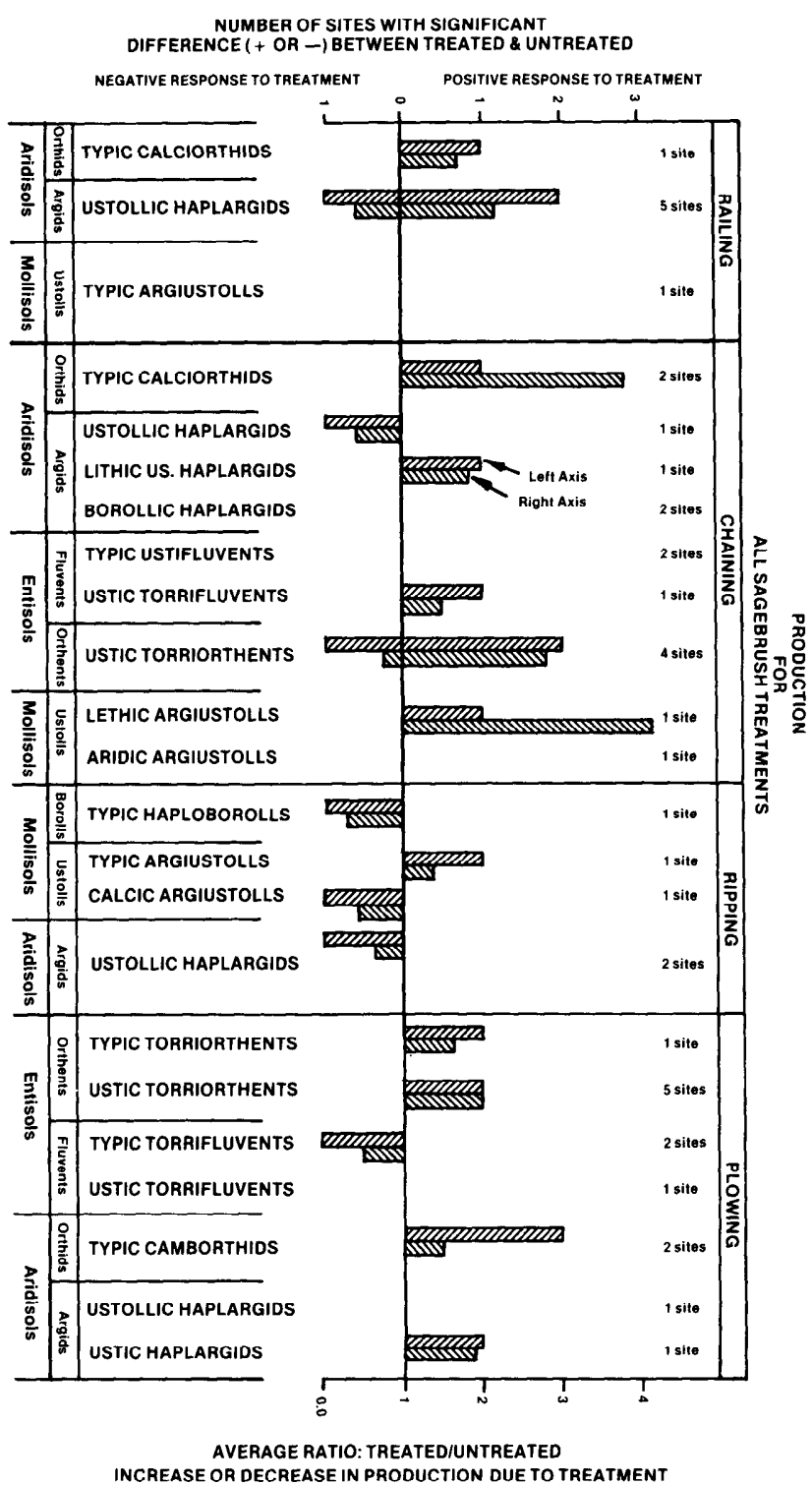

Fig. 6. Response of production (all species) on various sagebrush treatmen as a function of soils. For each pair of bars, the left bar corresponds to the le axis and the right bar corresponds to the right axis. Site numbers above $c$ below each set of bars represent total number of sites sampled within a give category. Bars represent only those sites where significant difference. $\mathrm{P}=0.1$ ) occurred (either + or - ). 


\section{loam soil was significantly decreased due to railing.}

Figure 6 indicates that annual production on two of the five sites on ustollic haplargid soils was significantly increased due to railing, while production on one site with the same soil type was significantly decreased. Annual production on a single site on typical calciorthid soils significantly increased due to treatment.

\section{Sagebrush Ripping}

Five of 13 sagebrush ripping sites showed a significant increase in annual production due to treatment. As shown in Figure 5, onc site was on sandy clay loam soil, three sites were on clay loam soils, and one site was on a clay soil. One site (out of 13,), on clay loam soil, had significantly less production on the treated portion.

From Figure 6 it is apparent that most favorable response to ripping occurred on typic torriorthents, typic camborthids, and ustic haplargids. Sites on other soil types either responded NUMBER OF SITES WITH SIGNIFICANT

DIFFERENCE ( + OR -) BETWEEN TREATED \& UNTREATED

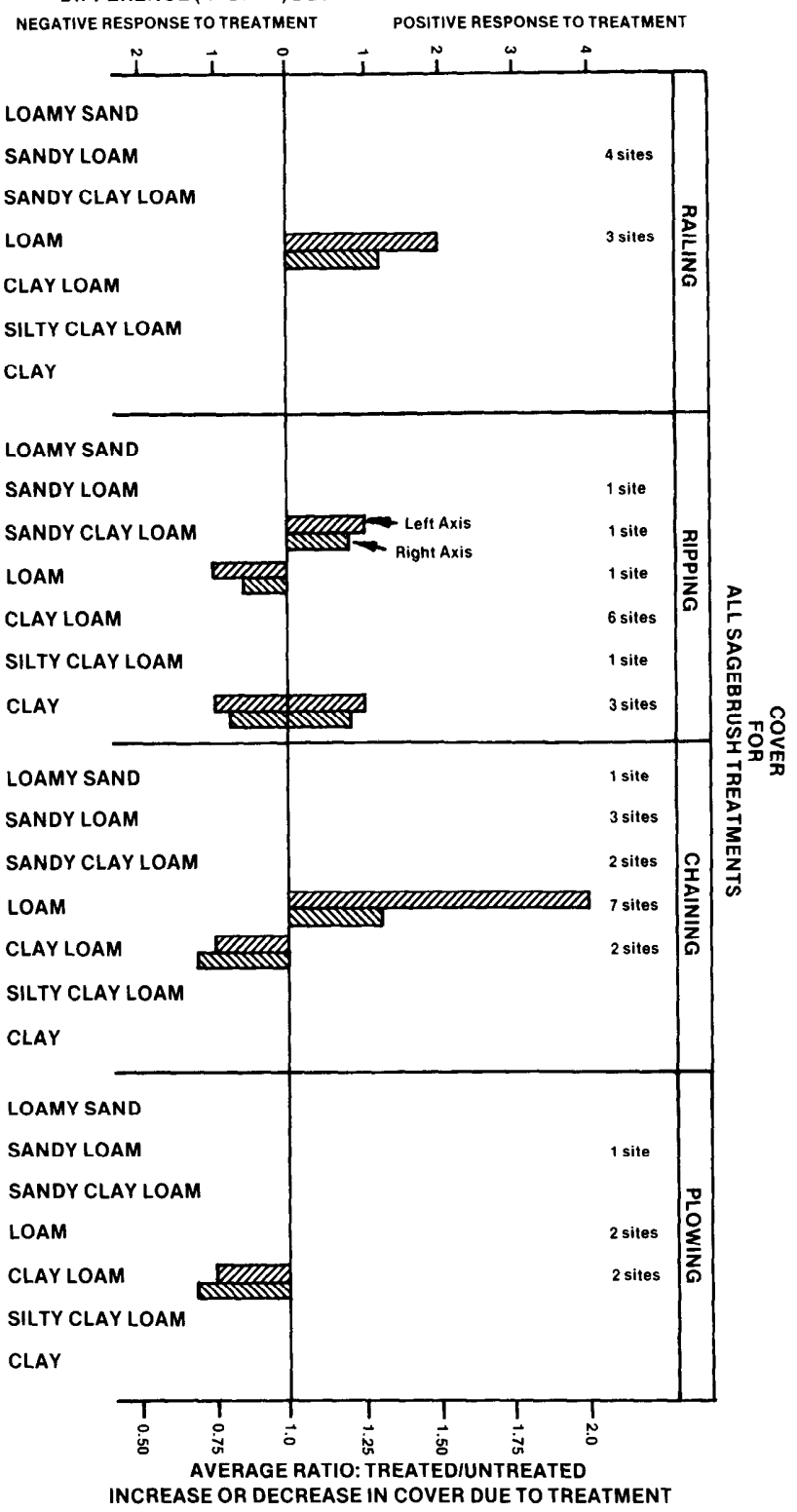

Fig. 7. Response of cover (vegetation, litter, rock) on various sagebrush treatments as a function of soil texture. For each pair of bars, the left bar corresponds to the left axis and the right bar corresponds to the right axis. Site numbers above or below each set of bars represent total number of sites sampled within a given category. Bars represent only those sites where significant differences $(\mathrm{P}=0.1)$ occurred (either + or - ). negatively to treatment, showed no response whatsoever, or showed a poor response to treatment (for example, one site out of five on ustic torriorthents).

\section{Sagebrush Chaining}

The most favorable response to chaining sagebrush was on loam soils, though not all sites showed a significant response to treatment and one site showed a significant decrease in production due to treatment (Figure 5). The most favorable sites appeared to be those on sandy clay loam and clay loam soils.

Figure 6 shows a mixed response to soil type, though the greatest increases in production were noted on typic calciorthids and lethic argiustolls. The least favorable sites were on ustollic haplargids, borollic haplargids, typic ustifluvents, and aridic argiustolls.

\section{Sagebrush Plowing}

Plowing was effective in increasing production on one site

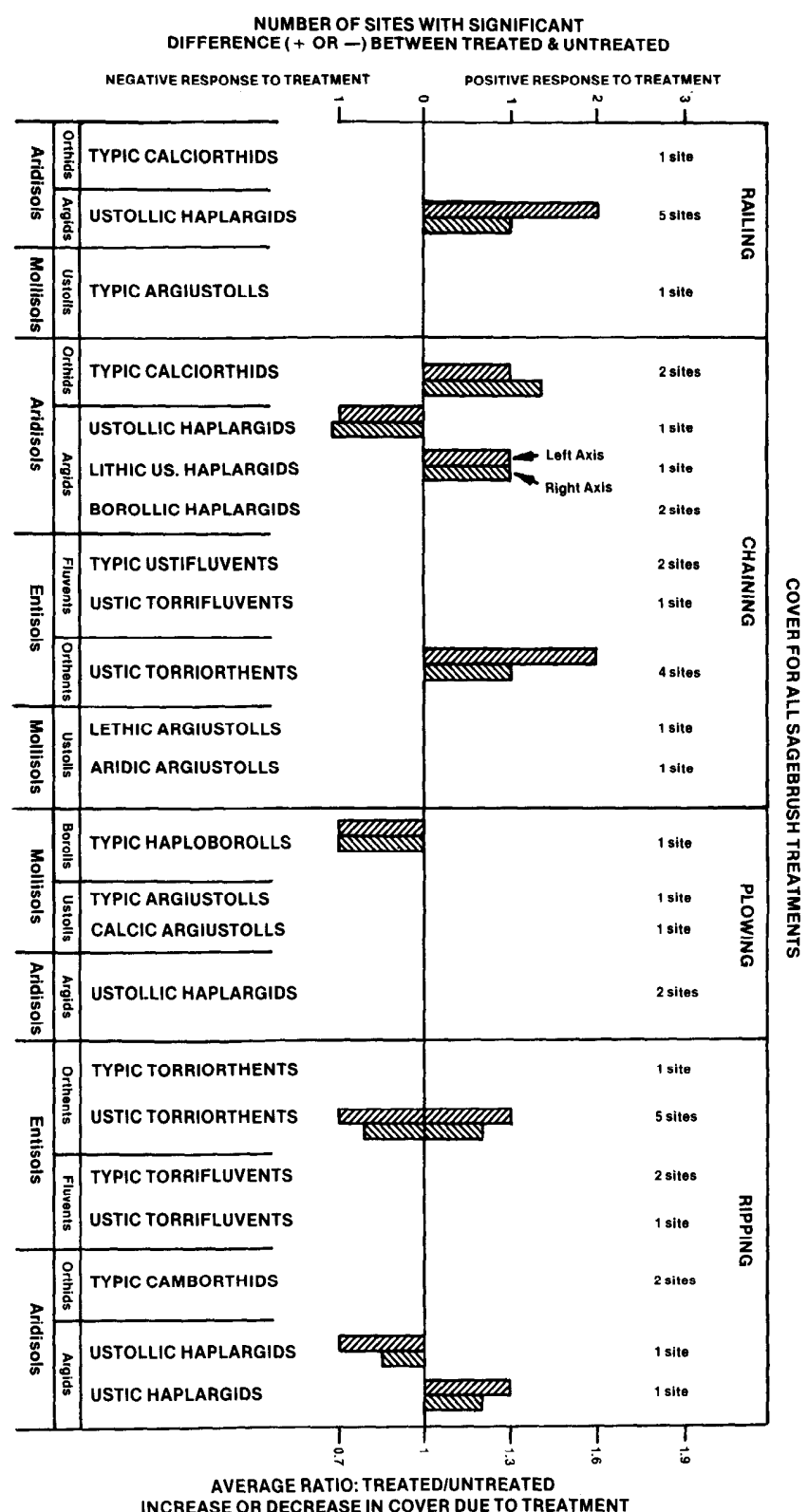

Fig. 8. Response of cover (vegetation, litter, rock) on various sagebrush treatments as a function of soils. For each pair of bars, the left bar corresponds to the left axis and the right bar corresponds to the right axis. Site numbers above or below each set of bars represent total number of sites sampled within a given category. Bars represent only those sites where significant differences $(\mathrm{P}=0.1)$ occurred (either + or -$)$. 
out of five. Soil on the one favorable site was classified as a typic agriustoll (Fig. 6).

\section{Cover Measures}

\section{Contour Furrowing}

Cover on 7 of 11 contour furrow treatment sites increased across a broad spectrum of soil textures and soil types (Figs. 1 and 2). Cover increases were greatest on sandy clay loam and loam textured soils and on typic torriorthent and ustic torriorthent soil types.

\section{Pinyon-Juniper Chaining}

Though cover increases due to chaining were noted on 8 of 14 pinyon-juniper sites on a variety of soil textures and soil types, the increases were uniformly small (Fig. 3 and 4). No clear pattern emerged from either soil texture or soil type.

\section{Pitting}

Significant changes in percent cover due to pitting were not detected on either the sandy clay loam or clay textured site sampled in this study, and so were not illustrated.

\section{Various Sagebrush Treatments \\ Railing}

As indicated in Figure 7, the only sites showing increased cover on railed treatments were those with a loam texture and with soils classified as ustollic haplargids (Fig. 8). Four sites with sandy loam soils showed no response to railing in terms of either increased or decreased cover.

\section{Ripping}

Cover responses to ripping treatments on sagebrush sites were mixed and generally not impressive (Fig. 7 and 8). Recommendations based on either soil type or soil texture are not evident at this time.

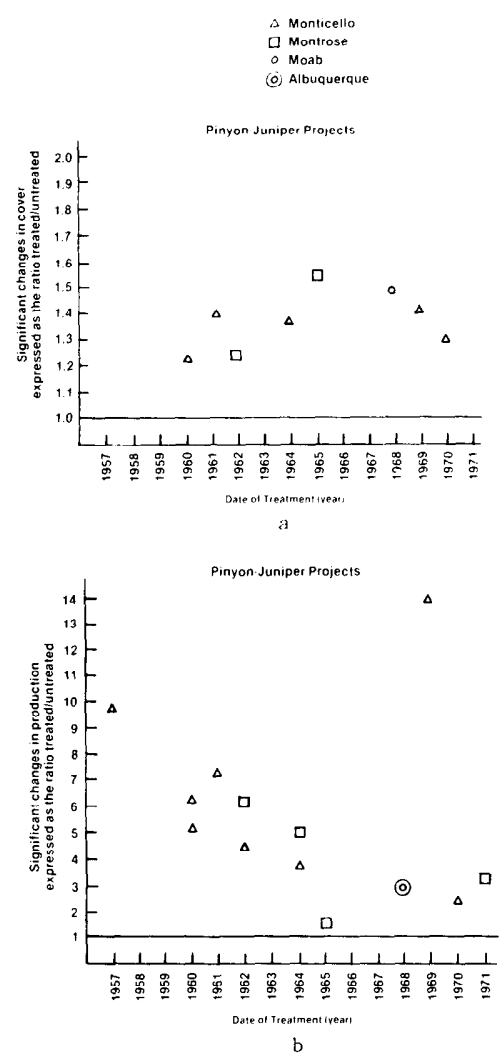

Fig. 9. Impact of age of treatment on significant changes in cover (a) and production $(b)$ due to chaining pinyon-juniper.

\section{Chaining}

The only sites showing increased over due to chaining were four of seven sites on loam soils (Fig. 7) classified as typic claciorthids, lithic ustollic haplargids, or ustic torriorthents (Fig. 8). Cover response to chaining was otherwise nil or negative.

\section{Plowing}

Of the five plowing treatments sampled, not a single one indicated increased cover on the treated area (Fig. 7 and 8 ). One site on clay loam soils indicated a significant decrease in cover on the treated area.

\section{Impact of Treatment Age on Production and Cover Contour Furrowing}

Age of treatment made little difference as to whether there was a significant increase or decrease in either production or cover on contour furrowed sites.

\section{Pinyon-Juniper Chaining}

Figure 9 indicates the impact of age of treatment on significant changes in production and cover due to chaining pinyon and juniper. Figure 9 a suggests either that significant increases in cover (where they occur) are slightly more dramatic on more recent treatments (linear interpretation) or that treatments which are approximately 11 years old represent conditions most nearly ideal for enhanced cover (assuming again that an increase in cover occurs) (curvilinear interpretation). The former interpretation is probably more nearly correct. A linear interpretation of the data points also suggests that any cover differences that may exist would disappear after about 30 years.

Data shown in Figure $9 \mathrm{~b}$ suggests that pinyon-juniper sites chained since 1964 are not as favorable in terms of increased production as those chained prior to 1964 (1969 data point ignored). This is understandable in that the pinyon-juniper sites with greatest potential would probably have been chained first. Another possible explanation is that a period of transition or establishment exists for about 10 years, followed by increasing

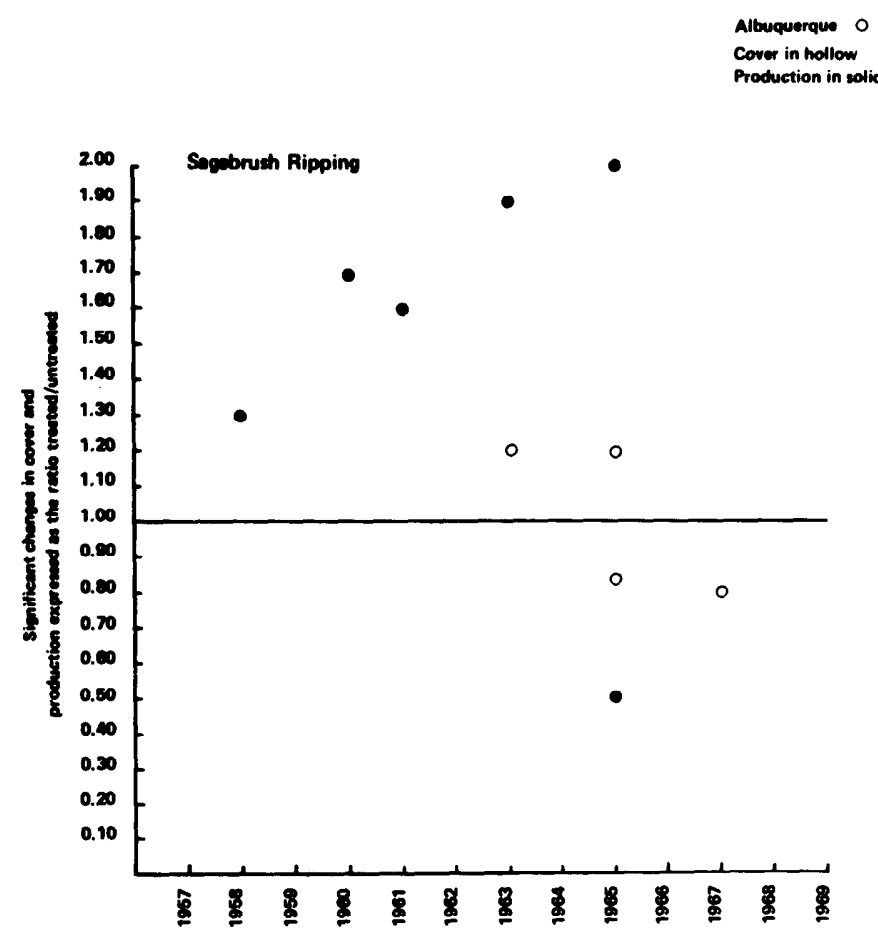

Fig. 10. Impact of age of treatment on significant changes in cover and production due to sagebrush ripping. 
rates of production as shown for older treatments.

\section{Various Sagebrush Treatments}

\section{Sagebrush Railing}

There was little evidence that age of treatment (within the limits of this study) had any impact on measured site response.

\section{Sagebrush Ripping}

Significant increases or decreases in cover or ripped sagebrush sites showed no apparent trend with respect to age of treatment, as shown in Figure 10. If one ignores the 1965 production data plotted at 0.50 in Figure 10, then a trend indicates that production increases (if they occur) are slightly more dramatic for more recent treatments than for older ones, and that increases, once established, might be expected to last for about 20 years.

\section{Sagebrush Chaining}

Data indicates no clear pattern as to the influence of age of chaining treatment on significant changes in either production or cover.

\section{Sagebrush Plowing}

Plowing treatments sampled in this study were nearly all detrimental in terms of increasing cover or production on the treated site, regardless of age of treatment.

\section{Summary and Conclusions}

During 1976 a land treatment study was conducted in Utah, Colorado, New Mexico, and Arizona. The range improvement practices studied included gully plugs, contour furrowing, pitting, pinyon-juniper chaining, and various sagebrush control treatments. Specific objectives of this study were to investigate the impacts of the various range improvement practices on watershed cover and annual production. The following summarizes the various findings:

1. About $33 \%$ of the contour furrowed sites indicated significant increases in annual production. The best responses were associated with loam or clay loam soil textures. Soils classified as typic ustifluvents or ustollic haplargids were most favorable in terms of increased production, while production on soils classified as typic cryoboralfs or typic argiborolls decreased significantly.

2. Annual production significantly increased due to pinyonjuniper chaining across a variety of soil types (growth of trees excluded on both treated and untreated sites). The greatest increases in production were associated with loam soil sites classified as typic haplustolls, while the smallest increases were on sites characterized by aridic argiborolls.

3 . From the two pitting treatments a significant reduction in annual production due to treatment was noted on a clay soil classified as a typic torriorthent, while on a sandy clay loam site classed as a typic torrifluvent no impact of pitting was measured.

4. Less than $50 \%$ of the various sagebrush treatments showed increased annual production. Sagebrush treatments appear to be most successful on loam soils, though significant decreases in production were noted for $23 \%$ of the treatments on loam soils.
Plowing was the least successful sagebrush treatment studied.

5. Cover of $67 \%$ of contour furrowed sites increased across a variety of soil textures and soil types. Cover increases were greatest on sandy clay loam and loam soil and typic torriorthent or ustic torriorthent soil types.

6 . Increases on cover due to chaining were noted on $57 \%$ of the pinyon-juniper sites across a variety of soil textures and soil types. However, the increases in cover were uniformly small (tree cover included on both treated and untreated sites), and no clear trend was indicated with either soil texture or soil type.

7. Significant changes in cover due to either of the two pitting treatments were not detected.

8 . Increases in cover were noted on $29 \%$ of the railed sagebrush sites with no impact on cover for the remaining $71 \%$.

9. Increases in cover were noted on $27 \%$ of the chained sagebrush sites. Seven percent indicated reduction in cover and the remaining $66 \%$ showed no impact on cover.

10. Significant reductions in cover were noted on $20 \%$ of the plowed sagebrush sites. The remaining $80 \%$ of the plowing treatments had no impact on cover.

11. Increase in cover was noted on $15 \%$ of the ripped sagebrush sites. Fifteen percent indicated reduction in cover and the remaining $70 \%$ had no impact on cover.

12. Age of contour furrowing treatments made little difference as to whether there was a significant increase or decrease in either production or cover.

13. Increases in cover (where they occur) are either slightly more dramatic on more recent pinyon-juniper chainings or on those treatments which are approximately 11 years old and represent conditions most ideal for enhanced cover (if it occurs). The former interpretation is probably more nearly correct. Production data suggest that pinyon-juniper sites chained since 1964 are not as favorable in terms of increased production as those chained prior to 1964 .

14. Age of sagebrush treatments had no impact on increases or decreases in cover; however, some general trends indicated that production increases (if they occur) on select sagebrush treatments are slightly more dramatic for more recent treatments than for older ones.

\section{Literature Cited}

Evans, R.A., and R.M. Love. 1957. The step-point method of sampling, a practical tool in range research. J. Range Manage. 10:208-212.

Gifford, G.F. 1975. Beneficial and detrimental effects of range improvement practices on runoff and erosion. In: Proc. A.S.C.E. Symp., Watershed Management, Utah State University, Aug. 11-13, Logan: 216-248.

Pechanec, J.F., and G.D. Pickord. 1937. A weight-estimate for the determination of range or pasture production. J. Amer. Soc. Agron. 29:894-904.

U.S. Dep. of Agriculture. 1975. Soil Conservation Service-soil taxonomy. A basic system of soil classification for making and interpreting for making and interpreting soil surveys. U.S. Dep. Agr. Agr. Handbk No. 436.

Wight, J.R. 1975. Land surface modifications and their effects on range and forest watersheds. In: Proc. 5th Workshop, U.S./Australia Rangelands Panel, Boise, Idaho, June 15-22:165-174.

Wilson, L., M.E. Olsen, T.B. Hutchings, A.R. Southard, and A.J. Erickson 1975. Soils of Utah Agr. Exp. Sta. Bull. 492, Logan: 94 p. 